\title{
Survey of Dairy Management Practices on One Hundred Thirteen North Central and Northeastern United States Dairies
}

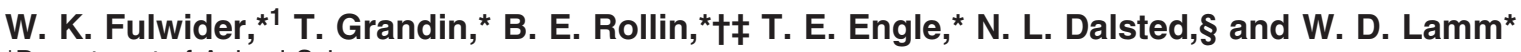 \\ *Department of Animal Sciences, \\ †Department of Philosophy, \\ ‡Department of Biomedical Sciences, and \\ $\S$ Department of Agricultural and Resource Economics, Colorado State University, Fort Collins 80523
}

\begin{abstract}
The objective was to conduct a broad survey of dairy management practices that have an effect on animal well-being. Dairies were visited during the fall and winter of 2005 and 2006 in Wisconsin, Minnesota, Indiana, Iowa, and New York. Data were collected on 113 dairies on colostrum feeding, dehorning, tail-docking, euthanasia methods, producer statements about welfare, use of specialized calf-raising farms (custom), level of satisfaction with calf-raising by producers, and cow behavior. Calves were raised by the owner on $50.4 \%$ of dairies; $30.1 \%$ were raised on custom farms during the milkfeeding period, $18.6 \%$ were custom raised after weaning, and $1 \%$ sold calves with the option to buy them back as first-lactation heifers. A total of $51.8 \%$ of producers were very satisfied with their current calf-raising methods. Three feedings of colostrum were fed to the calves on $23.9 \%$ of dairies, 2 feedings on $39.8 \%$ of farms, 1 feeding on $31.0 \%$ of farms, and colostrum replacement products were fed on 5.3\% of farms. Many farms $(61.9 \%)$ provided $3.8 \mathrm{~L}$ at first feeding. Calves were dehorned at different ages by various methods. By $8 \mathrm{wk}, 34.5 \%$ of calves were dehorned. By $12 \mathrm{wk}$, $78.8 \%$ of calves were dehorned. The majority of calves were dehorned by hot iron $(67.3 \%)$. The remainder were dehorned by gouging (8.8\%), paste (9.7\%), saw (3.5\%), or unknown by calf owner (10.6\%). Anesthetic use was reported by $12.4 \%$ of dairy owners and analgesia use by $1.8 \%$. Tail-docking was observed on $82.3 \%$ of dairies. The most common reported docking time was pre- or postcalving $(35.2 \%)$. The second most commonly reported time was d $1(15.4 \%)$. Rubber band was the most common method (92.5\%), followed by amputation (7.5\%). Three dairies amputated precalving, 1 at 2 mo and 3 at $\mathrm{d} 1$ or 2 . Cow hygiene was the most common reason given to dock (73.5\%), followed by parlor worker
\end{abstract}

Received August 22, 2007.

Accepted December 20, 2007.

${ }^{1}$ Corresponding author: Wendy.Fulwider@ColoState.edu comfort $(17.4 \%)$ and udder health (1.0\%). Producers reported $2.0 \%$ of cows obviously lame. Gun was the preferred euthanasia method (85.7\%), followed by i.v. euthanasia (8.0\%), live pick-up (1.8\%), and nondisclosure (3.5\%). Most producers (77.9\%) stated that cows were in an improved environment as compared with $20 \mathrm{yr}$ ago, whereas $8.0 \%$ stated conditions were worse, and $14.2 \%$ were undecided. Dairies with higher percentages of cows that either approached or touched the observer had lower somatic cell counts. The survey results showed management practices that were important for animal welfare.

Key words: behavior, dairy management, tail dock, calf rearing

\section{INTRODUCTION}

There is increasing societal concern about the moral and ethical treatment of animals (Rollin, 2004). To enable the dairy industry to effectively respond to these concerns, there is a need for more in-depth data on management practices that are actually being used. The data in the scientific literature are limited. Previous surveys of dairy management practices were predominantly conducted by mail (Bewley et al., 2001; Kellogg et al., 2001; Caraviello et al., 2006). One disadvantage of mail surveys is that a low percentage of producers respond. In these 3 surveys, the response rate was $48.0,67.3$, and $51.5 \%$, respectively. Often in a mail survey the perception by the dairy producer of a problem may differ from what actually exists. For example, Webster (2005) found that producers greatly underestimated the percentage of lame cows. There is a need for a survey in which an investigator actually visits a large number of dairies. This would help to provide more accurate data on the use of common husbandry and management methods. Previous field research in which an investigator visited dairies is limited. Espejo and Endres (2007) visited 50 dairies in Minnesota. Cook et al. (2004) and Schreiner and Ruegg (2002) conducted field studies on 12 and 8 dairies, re- 
spectively, in Wisconsin. One objective of our study was to survey a larger number of dairies in 5 states. Another objective was to determine if cow behavior measures were related to cow productivity. Data were collected to assess other husbandry procedures that may affect cow behavior.

\section{MATERIALS AND METHODS}

This study was approved by the Institutional Animal Care and Use Committee and the Institutional Review Board. A total of 113 dairies in 5 states (WI, MN, NY, IA, IN) with a total of 90,162 cows were visited by the first author during a 4-mo period beginning October 14, 2005. There were 107 free-stall dairy farms that ranged from 80 to 4,286 cows, with a mean of 803 cows. Six compost pack dairies, which ranged in size from 66 to 195 cows, were also visited. These are the same dairies surveyed in Fulwider et al. (2007) study on stall base types.

The North American manufacturer of cow waterbeds, Advanced Comfort Technology Inc. (Reedsburg, WI) provided lists of dairies. There were 55 dairies with waterbeds, 26 with rubber-filled mattress, and 16 with sand beds. Producers were contacted, and an appointment was requested within a week. During the travels of the first author, 53 additional dairies were located by either stopping in while driving by or requesting names from the local equipment dealer, feed mill, university extension office, veterinary office, or participating producers. A total of 131 dairies were contacted, and $86.3 \%$ agreed to participate.

\section{Interview}

Information requested during the producer interview included the amount and frequency of colostrum feeding, calf age at dehorning and method, use of analgesia or anesthetic, age at tail-docking and method, reason for docking, and preferred method of euthanasia. During the interview, data were obtained on the use of bulls, estrous synchronization, lameness, and the use of recombinant bST (rbST). Each producer was asked if he or she raised his or her own calves or had them raised at a custom calf-raising facility. If calves were reared at a custom facility, producers were asked at what age calves left and returned to the dairy. Satisfaction with the calf-raising system was scored on a 1 to 5 scale that ranged from very satisfied to very unsatisfied. Producers were asked the following question, "Are cows better off today with regard to animal welfare than they were 20 yr ago? Please give reasons." Milk production and SCC were obtained from producer records.

\section{Behavioral Measurements and Observations}

Behavioral observations were done on 41 free-stall dairies where the cows could be easily observed when they exited the milking parlor. A pen of multiparous cows in early lactation was observed. If more than 1 pen of cows conformed to these criteria, the pen with the most multiparous cows was measured. The behavior of each cow in the pen was scored as it exited the milking parlor. To collect the behavior data, the observer stood at the parlor exit where the cows had to pass within 3 $\mathrm{m}$ of her.

Dairy cattle behavior was assessed by recording the number of cows that either approached within $1 \mathrm{~m}$ or made physical contact with the observer. The percentage of cows that touched or approached on these 41 farms was calculated and analyzed. On 72 dairies, it was too difficult to individually score cows at the parlor exit due to inadequate lighting during nighttime visits, too cramped a facility for safe observation, or the observer presence at the exit could have caused cows to balk and refuse to leave the parlor. These herds were subjectively categorized as either low or non-low flight zone. A herd was categorized as low flight zone if the cows readily approached within $1 \mathrm{~m}$ or touched the observer when she walked the length of the free stall or compost pack barn. Cows in nonlow flight zone dairies either ignored the observer or moved away. Dairies with individually scored cows or subjectively scored cows were analyzed separately and in combination.

\section{Statistics}

All statistics were calculated using the SAS program (SAS 9.1, SAS Institute Inc., Cary, NC). Frequencies for all categories were calculated individually using the FREQ procedure. Statistical evidence for significance for select categorical variables compared with other categorical variables was done using the Mantel-Haenszel $\chi^{2}$ procedure. Categorical variables with only 2 categories were compared with continuous variables using the $t$-test, and groups of continuous variables used the CORR procedure to compute correlations. The GLM procedure was used to calculate LSM when there were multiple categorical variables in the same models. Dairy was the experimental unit for all analyses.

\section{RESULTS AND DISCUSSION}

\section{Calf-Raising Method}

Half of the dairies raised their own heifer calves from birth to entry into the milking herd (50.4\%). Calves were raised by a custom heifer raiser for $30.1 \%$ of dairies during the milk feeding period. Calves on $22.1 \%$ of dair- 
Table 1. Number of colostrum feedings for newborn calves

\begin{tabular}{lc}
\hline Number of feedings & $\begin{array}{c}\text { Percentage } \\
\text { of dairies }\end{array}$ \\
\hline 1 feeding & 31.0 \\
2 feedings & 39.8 \\
3+ feedings & 23.9 \\
Colostrum replacement product & 5.3 \\
\hline
\end{tabular}

ies were sent to the custom raiser on $\mathrm{d} 1$ or 2 ; another $8.8 \%$ were sent on or between $\mathrm{d} 3$ and 7 . An additional $18.6 \%$ of dairies sent their calves to a custom raiser for at least a period of time after calves were weaned. One dairy sold calves to a custom raiser $(1 \%)$ with the option to buy them back precalving. Heifers returned to the dairy from 3 wk to 2 mo before their expected calving date on $21.2 \%$ of dairies. Producers were satisfied $(30.9 \%)$ or very satisfied $(51.8 \%)$ with their calf-raising methods on $82.7 \%$ of dairies. The rest were indifferent $(8.2 \%)$, dissatisfied $(6.4 \%)$, or very dissatisfied $(2.7 \%)$. Most producers preferred not to discuss their reasons for dissatisfaction.

\section{Colostrum Feeding}

Colostrum was fed to calves on $94.7 \%$ of dairies (Table 1); the rest received a colostrum replacement product due to Johnes disease on the dairy. The majority of dairies $(61.9 \%)$ fed $3.8 \mathrm{~L}$ of colostrum at the first feeding, $2.8 \mathrm{~L}(13.3 \%), 1.9 \mathrm{~L}(17.7 \%)$, and $1.8 \%$ fed calves to appetite. Seventy-seven percent of producers who raised their own calves provided more than 1 feeding of colostrum. Fifty-eight percent of producers who used a custom calf raiser provided more than 1 feeding of colostrum. Hopkins and Quigley (1997) reported that calves fed $3.8 \mathrm{~L}$ of colostrum in 1 or 2 feedings were equally effective in providing passive immunity. The mean colostrum consumption for calves fed colostrum once and to appetite was $3.0 \mathrm{~L}$, or $8 \%$ of BW. Calves fed 2 or $2+$ times in $24 \mathrm{~h}$ consumed 3.2 and $3.3 \mathrm{~L}$, respectively. Jaster (2005) found that Jersey calves provided with 2 colostrum feedings of $2 \mathrm{~L}$ at 0 and $12 \mathrm{~h}$ had higher $\mathrm{IgG}_{1}$ than calves fed $4 \mathrm{~L}$ at birth.

\section{Dehorning}

Age. Ninety-five percent of the calves were dehorned by $32 \mathrm{wk}$ (Table 2 ). Five percent of dairies were unaware of the age their calves were dehorned, because they were at a custom calf-raising facility at the time of dehorning. The majority of dairies $(67.3 \%)$ dehorned calves by 8 wk of age.

Method. Gas or electric dehorning irons were used on $67.3 \%$ of dairies; $10.6 \%$ of interviewees were unaware of
Table 2. Age of calf at dehorning

\begin{tabular}{lc}
\hline $\begin{array}{l}\text { Age at } \\
\text { dehorning }\end{array}$ & $\begin{array}{c}\text { Percentage } \\
\text { of dairies }\end{array}$ \\
\hline Don't know & 5.3 \\
wk 1 & 7.1 \\
wk 4 & 25.7 \\
wk 8 & 34.5 \\
wk 12 & 11.5 \\
wk 18 & 8.0 \\
wk 32 & 8.0 \\
\hline
\end{tabular}

the age or method of dehorning, because their calves were being custom-raised. Paste products were used on $9.7 \%$ of dairies. These producers chose paste because it was easy to apply to the very young calf. The remaining dairies used the gouge method $(8.8 \%)$ or sawed horns off $(3.5 \%)$ with hack, meat, or wire saws. Anesthetics were used by $12.4 \%$ of dairy owners and analgesics by $1.8 \%$.

Research clearly supports the use of both anesthetics and analgesics for dehorning (Stafford and Mellor, 2005). Faulkner and Weary (2000) found that a combination of sedatives (xylazine), a local anesthetic (lidocaine), followed by a nonsteroidal antiinflammatory medication (ketoprofen) reduced the pain response both during and after the procedure. These calves gained more weight $(1.2 \pm 0.4 \mathrm{~kg})$ during the $24 \mathrm{~h}$ after dehorning than calves in the control group $(0.2 \pm 0.4 \mathrm{~kg})$. Caustic paste dehorning of calves was a simpler, less invasive procedure than dehorning with a hot iron. Paste dehorning of calves sedated with xylazine had a pain response that was less than calves dehorned with a hot iron and treated with a sedative and a local anesthetic (Vickers et al., 2005).

\section{Tail-Docking}

Most dairies (82.3\%) surveyed practiced tail-docking. Cow hygiene and worker comfort as affected by wet, dirty switches in the milking parlor were the most cited reasons. Little merit was found for docking with regard to health or hygiene, although there were differences between cows (Tucker et al., 2001). Tail-docking research by Purdue University scientists and USDA-ARS Livetock Behavior Research Center from 1997 to the present demonstrated that cow and heifer well-being can be compromised by acute pain, increased sensitivity, or chronic pain in the stump, as well as increased fly numbers and irritation (Eicher et al., 2001; Eicher and Dailey, 2002). The American Veterinary Association (AVMA, 2005) is officially opposed to tail-docking. The Canadian Veterinary Association is officially opposed to tail-docking, and the practice is prohibited in the United Kingdom (Stull et al., 2002). The first author 
observed no cows where the switches had been clipped or trimmed as an alternative to tail-docking. Many producers were adamant about continuing tail-docking for worker comfort. Three producers who conducted tours had quit tail-docking due to difficulty defending the practice.

Tail-docking and SCC are often mentioned in association with one another, although docking does not significantly affect SCC (Eicher et al., 2001; Schreiner and Ruegg, 2002). Dairies with tail-docked cows had an average SCC of 223,000 cells/mL as compared with nondocked cows at 237,000 cells $/ \mathrm{mL}(P=0.95)$. Many rapid exit parlors are now designed so that the tail does not come in contact with the milker. This would eliminate the need to dock tails for worker comfort. The discomfort suffered by cows at the time of docking and throughout life as a result of not being able to swish flies is not reasonable, because the only benefit is to milkers in the milking parlor. Matthews et al. (1995) reported that there were more flies on docked cows.

Tail-Docking Age. Heifer calves were docked on d 1 on $15.4 \%$ of dairies, $3.3 \%$ in wk $2,4.4 \%$ in the first month, $7.7 \%$ in the second month, and $14.3 \%$ in the fourth month. By 6 mo, $51.7 \%$ of calves had been docked. An additional $4.4 \%$ were docked by 1 yr, $8.8 \%$ by 18 mo, and $35.2 \%$ were docked either pre- or postcalving.

Tail-Docking Method. Banding with rubber calf castrating bands was the method of choice on $92.5 \%$ of the dairies where cows had docked tails. The remaining dairies $(7.5 \%)$ cut the tails off. Tree pruners were used to cut tails of adult cows on $2.7 \%$ of the dairies. Three producers cut tails on $\mathrm{d} 1$ or 2 , one producer at $2 \mathrm{mo}$, and 3 producers cut tails off before calving. Interviews indicated that pruning shears or tree pruners were the most common methods. Pain relief was not administered on any dairy after tail-docking. Producers did not think that this was a problem. If tails bled profusely, a band was applied. Tom et al. (2002) suggested that tail-docking caused only mild discomfort when the band was applied and that there was no advantage when epidural anesthetic was used. Tails were amputated below the ring $6 \mathrm{~d}$ later which appeared to cause mild discomfort. Until the long term effects of this procedure have been documented, alternatives to tail-docking should be considered (Tom et al., 2002). A few producers preferred to cut tails off, because banded tails fell off randomly, which caused problems in the manure handling system. Removing the tail after banding would have required handling animals a second time. Many producers stated that docking was less stressful on younger calves. Because there are different methods to perform these procedures, those that inflict the least pain should be used.

\section{Behavior and Breeding Methods}

Dairies with cows that were willing to approach the observer when they exited the parlor were correlated ( $\mathrm{r}=-0.31, P=0.05$ ) with lower SCC. Cows on dairies with longer waterers were more likely to touch or approach $(\mathrm{r}=0.35, P=0.05)$. A possible explanation is that the cows may be less stressed due to less competition over water.

Bulls were used on $37.5 \%$ of the dairies; within this group, $22.3 \%$ of bulls were housed with milking cows, $1.8 \%$ with dry cows or in a bull pen, and $13.4 \%$ were with heifers. A total of $36.9 \%$ of dairies used estrous synchronization protocols on $100 \%$ of their cows; synchronization usage of $<50 \%$ and $\geq 50 \%$ of the herd was 15.3 and $14.3 \%$, respectively, whereas $11.7 \%$ did not know. There was no synchronization program on $20.7 \%$ of herds.

Chi-square comparisons of the subjective behavior data indicated that estrous synchronization or bull presence had an effect. The greatest percentage of dairy herds $(44.8 \%, P=0.05)$ fell into the category of willing to approach and were herds that used estrous synchronization. Cows on dairies without bulls in the free-stall area $(42.9 \%, P=0.05)$ were more willing to approach. A likely explanation for this finding is that producers who used estrous synchronization protocols had more interaction between the cows and handlers than dairies that used bulls. The $t$-tests indicated that dairies with cows that were more willing to approach had lower stocking density $(P=0.05)$ and tendencies for lower percentages of lame cows $(P=0.07)$ and shorter calving intervals $(P=0.09)$. Calving interval, percentage of cows reported lame by the producer on the day of visit, and stocking density quartiles were reported in Table 3. Dairies were evenly split between 2 and 3 times daily milking frequency. Early lactation cows were milked 4 times daily on 7 dairies. In the later stages of lactation, the frequency of milking was reduced to twice or thrice daily.

\section{Posilac (rbST)}

On $71.7 \%$ of the dairies, rbST was used. The percentage of dairies using rbST by bed type was $53.6 \%$ for waterbeds, $70.2 \%$ for rubber-filled mattresses, and 93.1\% for sand beds. Monsanto reported increased incidence of hoof and hock problems and hoof disorders requiring medication (Collier et al., 2001). A possible explanation for the high percentage of rbST use on sand-bedded dairies is that sand beds had the lower levels of hock lesions compared with rubber-filled mattress (Fulwider et al., 2007). The rbST label cites adverse effects on fertility, increase in cystic ovaries, anorexia, bloat, swollen hocks, hoof lesions, and injection 
Table 3. Calving interval, percentage of lame cows, and stocking density

\begin{tabular}{lcccr}
\hline Item & Quartile 1 & Quartile 2 & Quartile 3 & Quartile 4 \\
\hline Calving interval (mo) $^{1}$ & 11.6 to 13.0 & 13.0 to 13.5 & 13.5 to 14.0 & 14.0 to 15.3 \\
Lame $^{1}(\%)$ & 0 to 0.6 & 0.6 to 1.5 & 1.6 to 2.8 & 2.9 to 10.4 \\
Stocking density $^{2}(\%)$ & 60.8 to 96.8 & 97.0 to 101.0 & 102.0 to 110.1 & 110.8 to 155.6 \\
\hline
\end{tabular}

${ }^{1}$ Percentage of cows reported lame on the dairy by the producer on the day of interview.

${ }^{2}$ The number of cows in the pen with the most multiparous cows in early lactation was divided by the number of available stalls to determine stocking density.

site reaction (Posilac label, http://www.monsanto.com). Bilby et al. (2004) reported lower conception rates in cows treated with rbST than in untreated cows. Willeberg (1993) reevaluated published data from rbST trials that indicated increased incidence of clinical mastitis by 15 to $45 \%$, whereas Kronfeld (1994) found increased mastitis incidence between 34 to $76 \%$. Crowd gates with electrified strips, chains, or wires were present on $4.4 \%$ of dairies. One producer indicated that the electric wire had been removed, because the milkers ran the chains over the cows. All but 1 of these dairies used rbST.

\section{Lameness}

Producers $(54.5 \%)$ identified papillomatous digital dermatitis as an issue they were concerned with. In our study, the percentage of cows reported lame ranged from 0 to $10 \%$. These self reports may be low compared with other studies in which lameness was scored. Webster (2005) reported that producers underestimated the percentage of lame cows. Our study may have surveyed a sample of better dairies. Forty-seven percent of the participants were nominated by other producers, equipment dealers, nutritionists, or veterinarians. In a study by Espejo et al. (2006), the top $10 \%$ of dairies had a lameness incidence of $5.4 \%$.

\section{Euthanasia}

Interviews indicated that gunshot was the preferred method of euthanasia on $85.7 \%$ of dairy farms. This is similar to the findings of Hoe and Ruegg (2006), who reported that $90.3 \%$ of dairies had euthanized an animal by gunshot within the last $3 \mathrm{yr}$. The most commonly used firearm was a 0.22 -caliber rifle. Some of the other firearms used were 9-mm pistol, 0.38-caliber pistol, 0.410 deer rifle, and a 12-gauge shotgun. Captive bolt, barbiturates, and gunshot have been approved as acceptable methods of euthanasia (AABP, 1999; AVMA, 2007). Only 1 dairy used a captive bolt. Dairy producers preferred gunshot, because it was quick, seldom failed, and they felt that it resulted in less overall suffering. Intravenous euthanasia was the preferred method on $8 \%$ of dairies. Live pick-up was reported on $1.8 \%$ of dairies. Producers were reluctant to provide details on live pick-up. Some producers would not disclose their euthanasia method (3.5\%).

Gunshot was used most often by the owner, herdsman, or the driver who removed the cows from the farm. Half of the producers who used the i.v. method had a veterinarian perform the procedure. The other half was performed by owners or herdsmen. Because euthanasia solution is not readily available to producers, disinfectants such as chlorhexidine were sometimes used. This is not approved by the AVMA (2007). It is likely that i.v. injection of a disinfectant would be painful, because disinfectants have no anesthetic or sedative properties.

\section{Animal Well-Being}

Producers were asked, "Are cows better off today with regard to welfare than they were $20 \mathrm{yr}$ ago? Please give reasons." The majority (77.9\%) thought dairy cow quality of life had improved. The reasons they gave were improved nutrition, housing, comfort, and veterinary care. The following is a summary of typical answers:

1. Nutritionists test feed and balance rations to optimize production, reproduction, hoof condition, and general health.

2. Veterinarians have regularly scheduled visits to check reproductive status, metabolic ills, and any other conditions of concern, as opposed to basic emergency care of the past.

3. Confinement provides high-tech ventilation systems that keep cows more comfortable during periods of hot weather.

4. Free stalls may be lined with resilient brisket locators or none at all. They may have stall dividers with open fronts and a lying area filled with sand, a waterbed, or a mattress filled with rubber crumbs.

5. Many producers suggested that the free stall is like a fancy hotel for cows, complete with room service. Cows are free to eat, drink, walk, and lie down at their leisure. More care and thought has gone into appropriate care as animal care has become more technologically advanced. 
A general conclusion that can be made from many interviews is that dairy producers felt that they were treating their cows well, because they follow the recommendations of university and veterinary specialists. They often are not considering the view from the perspective of a cow. The group of producers who felt that the quality of life of the cow had improved seldom mentioned a cow preferring pasture.

Some producers $(8.0 \%)$ felt that the overall changes in the industry had negatively affected animal wellbeing. The remaining $14.2 \%$ of producers felt that many areas of management had improved, but increased confinement had created new problems. These 2 groups of producers stated the following:

1. Twenty years ago, cows had more access to pasture, more individual care, and required fewer veterinary treatments.

2. Some problems were rbST use, rations high in concentrates, and total confinement on wet concrete. This has resulted in more health problems, displaced abomasums, and high percentages of cows with lameness and hoof problems have become part of the accepted management routine.

3. Twenty years ago, feed and veterinary bills were lower. Cows gave less milk per year, but they lived longer.

4. Producers who stated that animal well-being had not improved maintained that higher milk production had come at a great cost to the cows.

Pasture access would most likely result in healthier, more content, and comfortable cows. Outdoor exercise resulted in improved health, less lameness, and fewer tarsal joint lesions and teat injuries in a study by Regula et al. (2004).

\section{CONCLUSIONS}

The majority of producers surveyed on Midwest and eastern US dairies were making a good effort to quickly feed colostrum. Tail-docking was practiced on a high percentage of dairies. Painful procedures such as dehorning and tail-docking were being done at a younger age when producers felt it would be less traumatic, but only $12.4 \%$ used anesthetics. Perhaps hair could be trimmed from the switch to increase milker comfort. Dairies with cows that were more inclined to approach an observer were correlated with lower SCC. Gunshot was the most common euthanasia method, because it is perceived as causing the least pain and suffering. The majority of producers felt that changes in facilities and management had resulted in improved dairy cow well-being.

\section{ACKNOWLEDGMENTS}

We would like to thank all of the dairy producers who participated in this survey. We acknowledge financial support from Grandin Livestock Handling Systems Inc. (Fort Collins, CO) and Advanced Comfort Technology Inc. (Reedsburg, WI).

\section{REFERENCES}

AABP. 1999. Practical euthanasia of cattle. http://www.aabp.org/resources/euth.pdf Accessed Oct. 10, 2007.

AVMA. 2005. Policy statements: Tail docking of cattle. http://www.avma.org/issues/policy/animal_welfare/tail_docking_cattle.asp Accessed Aug. 21, 2007.

AVMA. 2007. AVMA Guidelines on Euthanasia. June 2007. http:// www.avma.org/issues/animal_welfare/euthanasia.pdf Accessed Aug. 22, 2007.

Bewley, J., R. W. Palmer, and D. B. Jackson. 2001. Modeling milk production and labor efficiency in modernized Wisconsin dairy herds. J. Dairy Sci. 84:705-716.

Bilby, T. R., A. Guzeloglu, S. Kamimura, S. M. Pancarci, F. Michel, H. H. Head, and W. W. Thatcher. 2004. Pregnancy and bovine somatotropinin nonlactating dairy cows. 1. Ovarian, conception, and insulin-like growth factor system responses. J. Dairy Sci. 87:3256-3267.

Caraviello, D. Z., K. A. Weigel, P. M. Fricke, M. C. Wiltbank, M. J. Florent, N. B. Cook, K. V. Nordlund, N. R. Zwald, and C. L. Rawson. 2006. Survey of management practices on reproductive performance of dairy cattle on large US commercial farms. J. Dairy Sci. 89:4723-4735.

Collier, R. J., J. C. Byatt, S. C. Denham, P. J. Eppard, A. C. Fabellar, R. L. Hintz, M. F. McGrath, C. L. McLaughlin, J. K. Shearer, J. J. Veenhuizen, and J. L. Vicini. 2001. Effects of sustained release bovine somatotropin (sometribove) on animal health in commercial dairy herds. J. Dairy Sci. 84:1098-1108.

Cook, N. B., T. B. Bennett, and K. V. Nordlund. 2004. Effect of free stall surface on daily activity patterns in dairy cows with relevance to lameness prevalence. J. Dairy Sci. 87:2912-2922.

Eicher, S. D., and J. W. Dailey. 2002. Indicators of acute pain and fly avoidance behaviors in Holstein calves following tail docking. J. Dairy Sci. 85:2850-2858.

Eicher, S. D., J. L. Morrow-Tesch, J. L. Albright, and R. E. Williams. 2001. Tail-docking alters fly numbers, fly-avoidance behaviors, and cleanliness, but not physiological measures. J. Dairy Sci. 84:1822-1828.

Espejo, L. A., and M. I. Endres. 2007. Herd level risk factors for lameness in high-producing cows housed in freestall barns. J. Dairy Sci. 90:306-314.

Espejo, L. A., M. I. Endres, and J. A. Salfer. 2006. Prevalence of lameness in high-producing Holstein cows housed in freestall barns in Minnesota. J. Dairy Sci. 89:3052-3058.

Faulkner, P. M., and D. M. Weary. 2000. Reducing pain after dehorning in dairy calves. J. Dairy Sci. 83:2037-2041.

Fulwider, W. K., T. Grandin, D. J. Garrick, T. E. Engle, W. D. Lamm, N. L. Dalsted, and B. E. Rollin. 2007. Influence of free-stall base on tarsal joint lesions and hygiene in dairy cows. J. Dairy Sci. 90:3559-3566.

Hoe, F. G. H., and P. L. Ruegg. 2006. Opinions and practices of Wisconsin dairy producers about biosecurity and animal wellbeing. J. Dairy Sci. 89:2297-2308.

Hopkins, B. A., and J. D. Quigley III. 1997. Effects of method of colostrum feeding and colostrum supplementation on concentrations of immunoglobulin $\mathrm{G}$ in the serum of neonatal calves. J. Dairy Sci. 80:979-983. 
Jaster, E. H. 2005. Evaluation of quality, quantity, and timing of colostrum feeding on immunoglobulin G1 absorption in Jersey calves. J. Dairy Sci. 88:296-302.

Kellogg, D. W., J. A. Pennington, Z. B. Johnson, and R. Panivivat. 2001. Survey of management practices used for the highest producing herds in the United States. J. Dairy Sci. 84:E120-E127.

Kronfeld, D. S. 1994. Health management of dairy herds treated with bovine somatotropin. J. Am. Vet. Med. Assoc. 204:116-130.

Matthews, L. R., A. Phipps, G. A. Verkerk, D. Hart, J. N. Crockford, J. F. Carragher, and R. G. Harcourt. 1995. The effects of tail docking and trimming on milker comfort and dairy cattle health, welfare and production. Pages 1-25 in Animal Behaviour and Welfare Research Center Rep. Minist. Agric. Forestry, Wellington, New Zealand.

Regula, G., J. Danuser, B. Spycher, and B. Wechsler. 2004. Health and welfare of dairy cows in different husbandry systems in Switzerland. Prev. Vet. Med. 66:247-264.

Rollin, B. E. 2004. Annual meeting keynote address: Animal agriculture and emerging social ethics for animals. J. Anim. Sci. 82:955-964.
Schreiner, D. A., and P. L. Ruegg. 2002. Effects of tail docking on milk quality and cow cleanliness. J. Dairy Sci. 85:2503-2511.

Stafford, K. J., and D. J. Mellor. 2005. Dehorning and disbudding distress and its alleviation in calves. Vet. J. 169:337-349.

Stull, C. L., M. A. Payne, S. L. Berry, and P. J. Hullinger. 2002. Evaluation of the scientific justification for tail-docking in dairy cattle. J. Am. Vet. Med. Assoc. 220:1298-1303.

Tom, E. M., I. J. H. Duncan, T. M. Widowski, K. G. Bateman, and K. E. Leslie. 2002. Effects of tail docking using a rubber ring with or without anesthetic on behavior and production of lactating cows. J. Dairy Sci. 85:2257-2265.

Tucker, C. B., D. Fraser, and D. M. Weary. 2001. Tail docking dairy cattle: Effects on cow cleanliness and udder health. J. Dairy Sci. 84:84-87.

Vickers, K. J., L. Neil, L. M. Kiehlbauch, and D. M. Weary. 2005. Calf response to caustic paste and hot-iron dehorning using sedation with and without local anesthetic. J. Dairy Sci. 88:1454-1459.

Webster, J. 2005. The assessment and implementation of animal welfare: Theory into practice. Rev. Sci. Tech. 24:723-734

Willeberg, P. 1993. Bovine somatotropin and clinical mastitis: Epidemiological assessment of the welfare risk. Livest. Prod. Sci. 36:55-66. 